\title{
Dilbilim Araştırmalarında Açık Bilim
}

\author{
Esra Ataman ${ }^{1}$, Ozan Can Çağlar ${ }^{2}$, Bilal Kırkıc1 ${ }^{3}$ \\ ORCID ID: ${ }^{1} 0000-0003-2359-6620,{ }^{2} 0000-0002-4824-3832,{ }^{3} 0000-0002-6423-$ \\ 7774
}

${ }^{1}$ Macquarie University, Department of Cognitive Science, NSW 2109 Australia

${ }^{1}$ Macquarie University, Centre for Reading, NSW 2109 Australia

${ }^{2,3}$ Orta Doğu Teknik Üniversitesi Ĕ̈itim Fakültesi Yabancı Diller Ĕ̈itimi Bölümü, 06800 Çankaya/Ankara

Iesra.ataman@hdr.mq.edu.au, ${ }^{2}$ caglar.ozan@metu.edu.tr, ${ }^{3}$ bkirkici@metu.edu.tr

(Gönderilme tarihi 12 Mayıs 2021; Kabul edilme tarihi 8 Ekim 2021)

ÖZ: Daha açık, şeffaf, tekrarlanabilir ve yeniden üretilebilir çalışmalar yürütmeye dikkat çeken açık bilimle ilgili tartışmalar, son yıllarda küresel alanyazında görünürlük kazanmaktadır. Bu tartışmalar, dilbilim alanında da kendine yer bulmuş, fakat Türkiye'de bu alanda açık bilime dair belirgin bir alanyazın henüz oluşmamıştır. Bu doğrultuda, bu makale tekrarlama krizi, bilimsel sahtekarlık ve yayın yanlılı̆̆ gibi açı bilime zemin hazırlayan gelişmelerin güncel bir özetini sunarak, şeffaflık, tekrarlanabilirlik ve yeniden üretilebilirlik gibi ilkelerin dilbilim araştırmalarında nasıl vücut bulabileceğini irdelemiştir. Makalede gizli esneklik ve sakıncalı araştırma uygulamaları sorunlarına dilbilim araştırmaları özelinde odaklanılmış ve bu sorunların ciddiyetine yönelik bir farkındalığın oluşturulması amaçlanmıştır. Bu sorunlara karş1 alanyazında önerilmiş dört temel çözüm önerisi (ön kaylt, yeniden üretilebilir iş akışı, ön baskı ve veri/materyal paylaşımı) artı ve eksileriyle tartışılarak, dil araştırmacılarının dikkatine sunulmuştur. Araştırmacıların bu çözüm önerilerini kendi alan ve koşullarını düşünerek değerlendirmeleri ve olabildiğince uygulamaları, dilbilim araştırmalarında şeffaflık, tekrarlanabilirlik ve yeniden üretilebilirliği artırmaya katk1 sağlayacaktır.

Anahtar sözcükler: açık bilim, şeffaflık, gizli esneklik, ön kayıt

\section{Open Science in Linguistic Research}

ABSTRACT: Discussions about open science, which draws attention to conducting more open, transparent, replicable, and reproducible studies, have been making an appearance in the global literature in recent years. These 
discussions have also found their place in linguistics, though there is no wellestablished literature on open science in this field in Turkey yet. Accordingly, by presenting an up-to-date summary of developments that pave the way for open science, such as the replication crisis, scientific fraud, and publication bias, this article examines how related principles such as transparency, replicability, and reproducibility can manifest themselves in linguistic research. In the article, the problems of hidden flexibility and questionable research practices are discussed within the scope of linguistic research with the aim of raising awareness about the seriousness of these problems. Four basic solutions suggested in the literature to avoid these problems (pre-registration, reproducible workflow, preprint, and data/material sharing) are presented together with their pros and cons and are brought to the language researchers' attention. It is possible to increase transparency, replicability, and reproducibility in linguistic research when researchers evaluate these proposed solutions in the literature by considering their own fields and conditions and apply them to the extent possible.

Key words: open science, transparency, hidden flexibility, pre-registration

\section{Açık Bilimin Tarihine Kısa Bir Bakıș}

Açık bilim, bilimsel çalışmaları şeffaflık, özen ve açıklık ilkelerine dayanarak gerçekleştirmeyi ve bu çalışmalar sonucu tekrarlanabilir (İng. replicable) ve yeniden üretilebilir (İng. reproducible) bulgular elde edebilmeyi hedefleyen bilim anlayışı için kullanılan kapsayıcı bir terimdir (bkz. Crüwell, 2019; Spellman vd., 2018). Bu bilim anlayıșının yakın dönemde hız kazanmasına zemin hazırlayan çeşitli nedenlerden bahsedilebilir.

$\mathrm{Bu}$ nedenlerin en başında, geçmişte farklı alanlarda rapor edilmiş ve ses getiren bilimsel bulguların, yakın zamanda başka çalışmalar tarafından tekrar edilememiş olması gelmektedir (Ioannidis, 2005). Bu sorun alanyazına tekrarlama krizi ${ }^{1}$ (İng. replication crisis) olarak girmiş ve sağlık bilimleri, psikoloji ve ekonomi başta olmak üzere, birçok alanda önemli kabul edilen bulguların tekrarlanabilirliğinden şüphe edilmesine neden olmuştur (Open Science Collaboration, 2015). Örneğin, son yıllarda bazı alanlarda ulaşılan birtakım sonuçların tekrar edilip edilemeyeceğini görmek adına tekrar çalışması projeleri hayata geçirilmiştir. Aynı yöntem ve materyallerle benzer örneklemler üzerinden yürütülen bu tekrar çalışmalarında, rastgele seçilen hedef çalışmalardan oldukça azının sonuçları tekrarlanabilmiştir (örnek, ekonomi: Camerer vd., 2016; psikoloji: Open Science Collaboration, 2015).

1 'Tekrarlama Krizi' bazen, çalışmaların tekrarlanabilmesinden kaynaklı bir soruna işaret ediyor gibi algılanabilir. Ancak metinde kriz sözcüğü, 'bir şeyin çok az bulunması durumu (bkz. https://sozluk.gov.tr/) anlamına gelmektedir. Dolayısıyla, 'tekrarlama krizi' tekrarlama durumunun nadir olarak görüldüğü bir duruma karşılık gelmektedir. 
Tekrar çalışmalarındaki tekrarlanabilme başarısı ölçütleri (örnek, $p$ değeri, etki büyüklüğ̈̈, tekrar çalışmasını yürüten kişilerin öznel değerlendirmesi vb.) zaman zaman değişkenlik gösterse de burada odaklanılması gereken temel nokta, tekrar çalışmalarında aynı materyaller/yöntemler kullanılsa dahi çoğunlukla kaynak çalışmaların bulgularını destekleyici kanıtların sağlanamamış olmasıdır. Buna ek olarak, Baker ve Dolgin (2017) kanser araştırmaları dahil olmak üzere birçok alanda kaynak çalışma ayrıntıları şeffaf bir şekilde paylaşılmadığı için tekrar çalışmalarının sayısının az olduğunu öne sürmüştür. Tekrar çalışması gerçekleştirmedeki bu zorluklar da belli bir alandaki bulguların ne ölçüde tekrarlanabildiği konusunda net bir bilgiye ulaşılmasını güçleştirmektedir.

Diğer nedenler arasında, ortaya çıarılan akademik sahtekarlık vakalarındaki (veri uydurma, veriyi çarpıtma, intihal vb.) artış ve bunun doğal sonucu olarak bilimsel bulgulara olan güvenin azalması da gösterilebilir (Chambers, 2017). Bu tür vakalar sebebiyle geri çekme (İng. retraction) kavramı bilimsel yayın sürecinin bir parçası haline gelmiştir. Geri çekme, makalelerde kasitlı ya da kasitsız yapılan hataların belirlenmesi sonucunda, bu makalelerin yayından kaldırılmasıdır. Örneğin, birçok çalışmasında yayımladığı verilerini uydurduğu ya da çarpıttığ 1 fark edilen sosyal psikolog Diederik Stapel'in şu ana kadar 58 makalesi geri çekilmiştir (The Retraction Watch Leaderboard, 2015). Bununla birlikte, başka çok sayıda araştırmacının da çalışmalarının benzer şekilde geri çekildiği düşünüldüğünde, bilimsel sahtekarlık vakalarının bilimsel bulguların güvenilirliğine zarar veren oldukça yaygın bir sorun olduğu görülmektedir.

Bir diğer neden ise, yayın yanlıllğg (İng. publication bias) sonucu bilimin yığılgan ilerleme felsefesinden uzakta, yalnızca istatistiksel olarak anlamlı sonuç bulan ya da hakemler tarafından çarpıcı bulunan çalışmaların alanyazına kazandırılması olarak sıralanabilir (Ferguson ve Heene, 2012). Yayın yanlılığının doğal sonucu olarak, tekrar çalışmaları ve sifır sonuç (İng. null result) bulan çalışmalar alanyazında kendine yer bulamamakta ve araştırmacıların çekmecelerinde tozlanmaya terk edilmektedir ('Çekmecede Kalan Çalışmalar Sorunu, (İng. file-drawer problem) (Chambers, 2017; Rosenthal, 1979). Franco vd. (2014) sosyal bilimler alanında inceledikleri 249 çalışma arasında sıfır sonuç elde eden 49 çalışmanın yalnızca 10 tanesinin yayımlandığını ve bu 49 çalışmadan 31 tanesinin araştırmacılar tarafından hiç raporlaştırılmadığını/yayımlanmadığını bildirmiştir. $\mathrm{Bu}$ bulgulardan anlaşılabileceği gibi, yayın yanlılığı ve çekmecede kalan çalışmalar sorunu, bilimin yığılgan bir şekilde ilerlemesi ve kendini düzeltmesi için gerekli olan sıfır sonuçlar ve tekrar çalışmalarının alanyazında yer almasını engellemektedir. Bunun ne kadar ciddi bir sorun olduğu şu şekilde açıklanabilir: (a) bir etkinin yalnızca varlı̆̆ına dair kanıtlar sunan ön yargılı bir alanyazın yaratması, (b) sıfır sonuç bulan araştırmacıları çalışmalarını 
yayımlatabilmek için sakıncall araştırma uygulamalarına (SARU, Questionable Research Practices) ve hatta sahtekarlığa yönlendirmesi (Munafò ve Neill, 2016).

Akademik sahtekarlık, yayın yanlılığı, çekmecede kalan çalışmalar sorunu, tekrarlama krizi gibi sorunlar ve daha fazla şeffaf, yeniden üretilebilir ve tekrarlanabilir çalışmalar gerçekleştirmek için önerilen çözümler (örnek, ön kayıt, veri ve materyal paylaşımı, yeniden üretilebilir çalışma akışı vb.), hem oldukça yeni hem de sayıca fazla oldukları için özellikle genç araştırmacıların gözünü korkutabilmektedir. Lisansüstü öğrenciler ve kariyerinin başındaki araştırmacılar, bu kadar fazla aşamayı, bir anda nasıl öğrenip uygulayacaklarını kestiremeyebilirler. Ancak bu pratikleri uygulama konusuna 'ya hep ya hiç' mantığıyla yaklaşmak yerine, 'bir yerden başlayarak elinden geleni yapmak' şeklinde yaklaşmak daha yerinde olacaktır.

Öte yandan, araştırmacılar daha iyi bilimsel pratikler için nereden başlayacaklarını bilemeyebilir ya da bu pratiklerin kendi alanlarıla ilişkisini göremedikleri için açık bilimin kendileriyle ilgili bir konu olmadığ düşüncesine kapılabilirler (Kathawalla vd., 2021). Ancak gerçek şudur ki, açık bilim bilimsel çalışma yapan tüm araştırmacıları ilgilendiren sorunlara dikkati çekmektedir. Örneğin, bulguların birden fazla çalışma tarafından tekrar edilebilmesi o bulguların güvenilirliğini artırmaktadır. Tek bir çalışma ile bir etkinin varlığı ya da yokluğu hakkında kesin bir kanıya varmak çoğu alanda mümkün değildir. Başka bir örnek vermek gerekirse, yeniden üretilebilir bir iş akışına sahip olmak, diğer araştırmacıların aynı akışı kullanarak çalışmadaki olası sorunları tespit edebilmesine olanak sağladığından, mikro anlamda araştırmacıların ve makro anlamda bilimin kendini düzeltebilmesine olanak tanımaktadır. Ayrıca, bir araştırmanın sürecini/sonucunu, şeffaf bir biçimde okurlarla ve ilgili paydaşlarla paylaşmak ve bunlar konusunda gerekçe sunabilir olmak araştırmacıların temel sorumluluğudur.

'Kriz' sözcüğü, her ne kadar olumsuz veya istenmeyen bir duruma işaret etse de, tekrarlama krizi farklı disiplinlerde üretilmiş bilimsel çalışmalardaki yetersizliklerin sorgulanmasına yol açmış, bilimsel bulguların şeffaf bir şekilde paylaşılıp paylaşılmadığı, bunların tekrarlanabilirliği ve yeniden üretilebilirliği üzerine düşünme firsatı sunmuştur (bkz. Roettger, 2021; United Nations Educational, Scientific and Cultural Organization (UNESCO), 2016). Dilbilim araştırmaları ve dilbilimin alt alanları da bu tartışmalara kayıtsız kalmamıştır. Özellikle son on yılda, yukarıda sözü edilen kavramların dilbilim araştırmalarında kendini nasıl gösterdiği, yaşanan/yaşanması olası sorunların neler olduğu ve sosyal bilimlerin başka alanlarında önerilen çözümlerin dile odaklanan çalışmalara nasıl uyarlanabileceği konuşulmaya başlanmıştır (bkz. Coretta, 2020; Haven ve Van Grootel, 2019; Havron vd., 2020; Mertzen vd., 2020). 
Dünyada bir süredir tartışılmakta olan açık bilim uygulamalarının, Türkiye gündeminde de kendine yer bulmaya başladığ 1 görülmektedir. Yükseköğretim Kurulu (YÖK), Türkiye Bilimsel ve Teknolojik Araştırma Kurumu (TÜBİTAK) ve çeşitli üniversitelerin konuyla ilgili girişimleri bulunmaktadır. Genele bakıldığında, açık bilim tartı̧̧malarının Türkiye'de ağırlıklı olarak psikoloji alanında yoğunlaştığ dünyadaki çıkış noktalarından birinin psikoloji alanı olduğu düşünülürse, ülkemizdeki ilk girişimlerin yine bu alanda olması şaşırtıcı değildir. Dilbilim araştırmaları özelinde ise, Türkiye'de henüz ciddi bir girişim olmamıştır. Özellikle, değişen akademik dünyada lisansüstü öğrenciler ve kariyerinin başındaki araştırmacıların bu pratikler üzerine düşünerek bunları kendi alanlarına uygulamaları ve bu pratikleri tez danışmanlarıyla tartışmaları daha açık, şeffaf, tekrarlanabilir ve yeniden üretilebilir bir bilimsel araştırma kültürünün ortaya çıkmasında kilit rol oynayacaktır (Kathawalla vd., 2021; Schönbrodt, 2019). Bu bağlamda bu makale, açık bilim ile ilgili en temel kavram ve sorunları tanımlayarak, dil araştırmacılarında gerekli farkındalığın oluşmasına katkı sağlamayı amaçlamaktadır. Aynı zamanda, dünyada başka alanlarda kullanılmış bazı çözüm önerilerini dilbilim araştırmacılarının dikkatine sunarak, alanın ilerlemesine katkı sağlayacak sağlıklı tartışma atmosferinin oluşmasına zemin hazırlamayı hedeflemektedir.

\section{Dilbilim Araștırmalarında Şeffaflık, Tekrarlanabilirlik ve Yeniden Üretilebilirlik}

Bilimsel araştırma özelinde, 'şeffaflık' bir araştırmanın çeşitli evrelerinde verilen kararların (örnek, araştırma sorusu, uygulama ayrıntıları ya da analiz ayrıntıları) ve bu evreler sonucu elde edilen çıtılların tümünün (örnek, materyal, ham veri vb.) herkes tarafından erişilebilir şekilde paylaşılmasını kapsar. Bu şeffaflık sayesinde diğer araştırmacılar benzer kararlar verdiklerinde ne gibi sonuçlarla karşılaşabilecekleri, kendi yöntemlerini belirlerken neleri dikkate almaları gerektiği ya da sonuçlarını nasıl yorumlayabilecekleri hakkında fikir sahibi olabilirler. Dolayısıyla şeffaflık, gelecek çalışmaların kalitesinin artmasına yardımcı olan önemli bir ilkedir (Miguel vd., 2014). Örneğin, sesbilgisine odaklanan çalışmalarda, araştırmacının kararına bırakılan birçok aşama bulunmaktadır (örnek, hangi analiz tekniğinin kullanılacağı ya da akustik sesbilgisel yöntemlerin kullanıldığı analizlerde hangi değişkenlerin kullanılacağı gibi). Başka araştırmacıların belli bir veriyi yeniden analiz edebilmesi ve kendi çıkarımlarını yapabilmesi, ancak bu aşamalar okurla şeffaf bir şekilde paylaşıldığında mümkün olabilir (Roettger vd., 2019). Ayrıca şeffaflık ve açık erişim, alanyazındaki çalışmalarda gözden kaçan noktaların yahut hataların fark edilmesini sağlayarak bilimin kendi kendini düzeltmesine, alanyazında daha doğru ve güvenilir sonuçların birikmesine olanak tanır (Hoekstra ve Vazire, 
2020; Hui ve Huntley, 2020; Vazire, 2019). Yeniden üretilebilir analiz kodlarının ve çalışmaya ait verilerin paylaşılmaması, bilimin yı̆̆ılgan bir şekilde ilerlemesine engel olmaktadır. Buna ek olarak, belli bir konuya odaklanan çalışmaların bulgularının bir araya getirildiği meta-analiz benzeri sentezlerin yapılabilmesi, her çalışmanın kaynak verisine erişebilmeyle mümkün olabilmektedir (Vasishth vd., 2018).

Dilbilim araştırmaları, veri toplama sürecinde kullanılan görev, katılımcıların anadili, dil yeterlik düzeyi ya da ikidilli/çokdilli olma durumu gibi birçok unsur göz önüne alınarak değerlendirilmelidir. Dilbilim araştırmalarında göz önünde bulundurulması gereken unsurlardan bahsederken Aygen (2012), sistematik bir biçimde toplanmamış ve yalnızca dilbilgisel yargl görevine (İng. grammaticality judgment task) dayanan veriler sunan çalışmalarla ilgili bazı olası sorunlardan bahsetmiştir. Dilbilim araştırmacılarının kendi anadilleri üzerinden ve bu dil içindeki tüm çeşitler düşünülmeden ortaya koyacakları öznel yargıların ön yargı olma riskinden ve dilbilim alanındaki bulgulara olan güveni azaltabileceğinden bahsetmiştir.

$\mathrm{Bu}$ nedenle, yukarıda bahsedilen unsurların paylaşımı konusunda gösterilecek şeffaflık, dilbilim araştırmalarının yeniden üretilebilirliğini ve genellenebilirliğini belirleme konusunda başka araştırmacılara 1şık tutacaktır. Veri toplamada kullanılan görev ve materyallerin paylaşıldığ 1 bir veri tabanı (örnek, IRIS dijital veri tabanı, Marsden vd., 2016) birçok dil araştırmacısı tarafından aktif olarak kullanılmaktadır (Marsden vd., 2017). Bu paylaşımların artması dilbilim araştırmalarının kalitesini ve güvenilirliğini artıracaktır ve ortak bilgi birikimine katkı sağlayarak gelecek çalışmaları kolaylaştıracaktır (Roettger vd., 2019). Dahası, bu tür veri tabanları, kaynak çalışmada bulunan etkinin tekrarlanabilirliğini sınamak isteyen araştırmacılara kullanılan görev ve materyallere erişim konusunda kolaylık sağlamaktadır. Şeffaflık aynı zamanda son yıllarda tartışılan bilimsel pratikteki birçok sakıncalı araştırma uygulamasının önüne geçmede kilit bir role sahiptir (Chambers, 2017) (bkz. Gizli Esneklik ve Sakıncalı Araştırma Uygulamaları).

Alanyazında, tekrarlanabilirlik ve yeniden üretilebilirlik tanımlarıyla ilgili terminoloji karmaşasından söz edilmektedir (Marsden vd., 2018). Bu makalede, tekrarlanabilirlik yukarıda da bahsedildiği gibi, bir çalışmada elde edilen bulgulara aynı yöntemle ve aynı koşullar altında gerçekleştirilen başka bir çalışma ile ulaşmak şeklinde tanımlanabilir (Coretta, 2020). Yapılan tekrar çalışması kaynak çalışmayla aynı yöntemi kullanıyorsa 'doğrudan tekrar' olarak adlandırılır. Öte yandan, 'kavramsal tekrar' çalışmaları, kaynak çalışmayla aynı olguyu sınasa da kullanılan yöntem farklı olduğu için kaynak çalışmanın bulgularının geçerliliği ya da güvenilirliği konusunda yeterli bilgi sağlamayabilir. Mevcut sistemde, doğrudan tekrar çalışmaları bazı dergiler tarafından bilimsel yayın için yeterli ölçüde yeni ve özgün olarak değerlendirilmediği için reddedilebilmektedir. Ancak bu çalışmalar, bir etkinin 
varlığına dair güvenilir bulgular ortaya koymak ve yanlış pozitif (aslında var olmayan bir etkinin varlığına dair hatalı bir kanıt göstermek) etkilerin ortaya çıkarılması için oldukça önemlidir (Vasishth vd., 2018). Bu nedenle tekrarlama, bilimin temel prensiplerinden biri olarak gösterilebilir. Tekrarlamanın temel amacı bilimsel bulguların doğruluğunu teyit etmek, belli bir etkinin gözlemlendiği durumları açığa kavuşturmak ve etki büyüklüğünü hesaplamaktır (Klein vd., 2014).

Dilbilimde, psikoloji alanındakine benzer geniş çaplı tekrar çalışması projeleri henüz gerçekleştirilmemiştir. Bu konuda çağrılar yapılsa da (Marsden vd., 2017) tekrar çalışması girişimleri dilbilimin belirli alt alanlarına özel (örnek, tümce işlemleme, konuşma üretimi, ruhdilbilim) ve bireysel ölçekte sürdürülmektedir (Roettger ve Baer-Henney, 2018; Vasishth vd., 2018). Bu sebeple, dilbilimde önemli kabul edilen bulguların ne kadarının tekrar edilebildiği konusunda net bir şey söylemek pek mümkün gözükmemektedir.

Tekrar çalışmalarında yeni verilerin toplanması söz konusudur. Yeniden üretilebilirlik ise kaynak çalışmanın verilerinin başka araştırmacılar tarafından bağımsız bir biçimde analiz edilmesini kapsar; diğer bir deyişle, halihazırda toplanmış olan verinin yeniden ve en baştan analizi gerçekleştirilir (BerezKroeker vd., 2018; Coretta, 2020). Yeniden üretilebilirlik için uygun şartların sağlanması, bağımsız analizi gerçekleştirecek araştırmacıların kaynak çalışmanın verilerine ne ölçüde erişebildiğine bağlıdır. Yeniden üretilebilirliğin önemi, kaynak çalışmayla aynı şartların oluşturulmasının oldukça zor olduğu bazı alanlarda (örnek, yaşam bilimleri) daha iyi gözlemlenebilir.

Saha çalışmasına dayanan sosyal bilimlerin birçok alt alanında tekrarlanabilirlik için aynı şartların tam anlamıyla oluşturulması oldukça zor olabilmektedir. Dolayısıyla bu durumlarda, yeniden üretilebilirlik bilimsel özeni sağlama ve bulgulara olan güveni artırma konusunda önemli bir araç olabilir. Bu bağlamda, yeniden üretilebilirliğin getireceği bilimsel özen, karmaşık davranışları gözlemleyen dilbilim araştırmaları için de önemlidir. Örneğin, anlık konuşma (İng. spontaneous conversation), önceden hazırlanmış çıkartım/söyletim (İng. prepared elicitation) yahut dilbilgisel yarg1 görevi gibi dilbilimde sık kullanılan araştırma desenlerinde bir dil konuşucusunun belirli bir dilsel yapı yerine başka bir yapıyı tercih etmesinin nedenlerini kestirmek, kontrol etmek ve aynı şartları oluşturarak tekrarlamak kolay olmayabilir. Böyle bir durumda, var olan veri başka araştırmacılar tarafından yeniden analiz edilerek kaynak çalışmanın bulgularıyla aynı bulgulara ulaşılıp ulaşılamayacağı sınanabilir. $\mathrm{Bu}$ analizin gerçekleşmesi ancak kaynak çalışmanın verilerinin şeffaf bir şekilde paylaşılmasıyla mümkündür. Dilbilim araştırmalarının temelini oluşturan dilsel verinin erişilebilir, atıf verilebilir ve yeniden kullanılabilir olması, veri yönetimine, saklanmasına ve paylaşımına verilen önemin artması büyük önem taşımaktadır (Berez-Kroeker vd., 2018). 
Yeniden üretilebilirlik, tekrarlanabilirliğge bir alternatif olarak düşünülmemelidir. Aksine, yeniden üretilebilirlik beraberinde tekrarlanabilirliği de artıran önemli bir unsurdur. Tüm bu sebeplerden ötürü, dil çalışmaları tasarlanırken tekrarlanabilirlik ve yeniden üretilebilirlik aynı ölçüde göz önünde bulundurulmalıdır. Daha da önemlisi, tekrarlanabilirlik ve yeniden üretilebilirliğin sağlanmasının, temelde şeffaflık ilkesine bağlı kalmaktan geçtiği vurgulanmalıdır. Fakat bir sonraki başlık altında etraflıca incelendiği gibi, şeffaflık ilkesine bağlı kalmak araştırmacıların inisiyatifinde olduğundan, bu durum çalışma kapsamında uygulanan adımların ne ölçüde raporlaştırılacağı konusunda araştırmacılara önemli bir esneklik olanağı sağlayabilmektedir. Dolayısıyla bu, bilimsel çalışmaların güvenilirliği açısından ciddi sorunlara sebep olabilmektedir.

\section{Araştırmacı Serbestlik Derecesi/Gizli Esneklik ve Sakıncalı Araştırma Uygulamaları (SARU)}

Bilimsel araştırma yapan tüm araştırmacılar bir bilimsel çalışmayı gerçekleştirirken çalışmanın tüm aşamalarında (örnek, tasarlama, yürütme ya da veri analizi) çeşitli kararlar vermektedir. Dahası, bu kararları verirken çoğu zaman birden fazla seçenek arasından seçim yapmaları gerekebilmektedir. Örneğin, araştırmacıların araștırmak istedikleri konuyu sınamak için alanyazında birçok görev kullanılmış olabilir ve araştırmacılar kendi çalışmaları için hangi görevi kullanacakları konusunda kendi kararlarını vermek durumunda kalabilirler. Ayrıca, toplanan veriyi analiz etmek için çok çeşitli istatistiksel analiz yöntemleri bulunabilir. Bu noktada araştırmacılar öznel değerlendirmeler sonucu bir karar vermek zorunda kalabilirler. Aynı durum $u c ̧$ değer (İng. outlier) olarak kabul edilecek veri noktalarının ya da nihai analizden katılımcı çıkarma ölçütünün belirlenmesi için de geçerlidir. Araştırmacıların bahsi geçen kararlarda sahip oldukları seçim esnekliği Araştırmacı Serbestlik Derecesi (İng. Researcher Degrees of Freedom) veya Gizli Esneklik (İng. Hidden Flexibility) olarak adlandırılmaktadır. Tüm bu kararlar, araştırmanın seyrini ve sonuçlarını doğrudan etkileyebilmektedir. Buna karşın, araştırmacının hangi seçenekler arasından hangi ölçüte dayanarak bu kararları verdiği okurla şeffaf bir şekilde paylaşılmadığında yalnızca verilen son kararlarlar okura ulaşacak, karar sürecindeki esneklikler okurdan - bilerek veya istemeden - gizlenmiş olacaktır (Wicherts vd., 2016).

Araştırmacı serbestlik derecesi konusunda dilbilim araştırmalarında karışımıza çıkabilecek durumlardan ilki, çalışmanın ilerleyen aşamalarında bağımsız değişkene çevrilebilecek birtakım değişkenler hakkında bilgi toplamak olabilir (Wicherts vd., 2016). Örneğin, dilbilim araştırmalarında 
s1klıkla Katılımcı Artalan Sormacası (İng. Language Background Questionnaire) vasıtasıyla dil edinim yaşı, anadil (D1), cinsiyet ve kullanılan baskın el gibi demografik ve/veya kişisel veriler toplanmaktadır. Normal şartlar altında, bu bilgiler okura katılımcı profilini şeffaf bir şekilde tanıtmak amacıyla kullanılmaktadır. Ancak bu bilgiler zaman zaman çalışmanın veri analizi aşamasında bağımsız değişken(ler) olarak analize dahil edilebilmekte ve istatistiksel olarak anlamlılık etkisi olanlar en başından beri çalışma planında bulunuyormuş gibi rapor edilebilmektedir.

Aslında artalan verisi olarak toplanmış bir etkenin daha sonra bağımsız değişken olarak bir çalışmaya dahil edilmesinin ve bu durumun okurla paylaşılmamasının, çalışmadan yapılacak çıkarımların güvenilirliğine doğrudan etki edeceği göz önünde bulundurulmalıdır. Benzer şekilde, veri analizi aşamasında bu bilgilere dayanarak katılımcı çıkarmak (örnek, sol elini kullanan katılımcıları veri setine dahil etmemek) veya eklemek ve bunu açıkça okurla paylaşmamak da bulguların güvenilirliğini tehdit eden bir başka unsur olabilmektedir (Gelman ve Loken, 2019; Simmons vd., 2011; Wicherts vd., 2016).

Bir diğer araştırmacı serbestlik derecesi, veri toplama aşamasının sonlandırılacağı noktaya istenilen bulguların elde edilip edilmemesine bağlı olarak karar vermek ile ilgilidir. Bu durum, tüm disiplinlerde olduğu gibi dilbilim araştırmalarında da karşımıza çıkabilmektedir. Böyle bir senaryoda genellikle katılımcı sayısı çalışmanın tasarım aşamasında belirlenmemektedir. Aksine, herhangi bir sonlandırma kriteri belirlenmeden veri toplama süreci başlatılmakta ve toplanmakta olan bu veri, süreç devam ederken aralıklı olarak analiz edilerek istenilen sonuca (örnek, $p<.05$ ) ulaşılıp ulaşılmadığına bakılmaktadır. Dolayısıyla, veri toplama aşamasını sonlandırılma noktası, aralıklı olarak gerçekleştirilen bu analizlerin sonucuna bağlı olmaktadır (Simmons vd., 2011; Wicherts vd., 2016). Dilbilim araştırmalarında, özellikle bazı ikidilli/çokdilli gruplara yahut afazi veya disleksi tanısı almış bireylere ulaşmak ve bu kişileri bilimsel çalışmalara dahil etmek oldukça zor olabilmektedir. $\mathrm{Bu}$ durum araştırmacıları herhangi bir sonlandırma kriteri belirleyemeden veri toplama aşamasını başlatmaya itebilmektedir. Ancak burada unutulmaması gereken noktalar, bu durumun okurla ne ölçüde paylaşıldığı, çalışmada kullanılan istatistiksel yöntemin veri toplama devam ederken gerçekleştirilen bu analizlere olanak sağlayıp sağlamadığı ve bu analizlerin sonuçlarının çalışmanın sonunda yapılacak çıkarımları nasıl etkilediğidir.

Dilbilim araştırmalarında karşımıza çıkabilen bir başka gizli esneklik, çalışmada hangi değerlerin uç değer olarak kabul edileceğine verinin incelenmesinden sonra karar verilmesidir (Wicherts vd., 2016). Özellikle deneysel dilbilimde sıklıkla kullanılan doğruluk oranı (İng. accuracy rate) ya da tepki süresi (İng. reaction time) gibi bağımlı değişkenlerin bulunduğu 
çalışmalarda, kesme noktasının (İng. cut-off point) yüzde kaç (yani hangi hata oranına sahip katılımcıların çalışmaya dahil edilip hangilerinin edilmeyeceği) ya da kaç milisaniye olarak belirleneceği, sonuçlara doğrudan etki eden bir karardır. Bu karar veri incelendikten sonra verildiğinde ve bu durum okurla şeffaf bir şekilde paylaşılmadığında, araştırmacıların kesme noktasını kendi istedikleri sonuca ulaşmak adına rastgele şekilde belirledikleri şüphesi oluşabilir. Ayrıca böyle bir durum araştırmacıya istediği sonucu elde etme olanağı tanıdığından, bir hipotezin sinanmasından ya da bulguların güvenilirliğinden söz etmek güçleşebilir.

Bir araştırma sorusunun birden fazla deney ya da görev ile sınandığı çalışmalarda, bu deney ya da görevler sonucu elde edilen bulguların ne kadarının okurla paylaşılacağı ve bunun hangi ölçütlere göre belirlendiği yine bir gizli esnekliği beraberinde getirmektedir (Simmons vd., 2011; Wicherts vd., 2016). Örneğin, bir dil araştırmacısının, eşdeğer sözcüklerin (İng. cognates, örnek, Türkçe meteor ve İngilizce meteor) kontrol sözcüklere (örnek, Türkçe pusula ve İngilizce compass) oranla daha hızlı işlemlenip işlemlenmediğini incelemek amacıyla dört farklı deney gerçekleştirdiğini düşünelim. Bu deneylerden üçünün araştırmacının istediği sonucu verdiği, birinin ise farklı bir sonuç ortaya koyduğu bir durumda, araştırmacı çalışma sonuçlarındaki bu tutarsızlığın önüne geçmek için bir karar vermek zorunda kalabilir. Araştırmacı, bu durumu şeffaf bir şekilde olduğu gibi aktarmayı veya yalnızca beklediği sonucu destekleyen üç deneyi raporlaştırmayı tercih edebilir. Beklenilen sonucu desteklemeyen deneyin okurlarla paylaşılmaması durumunda, okurlar ve alanyazında aynı konuyu inceleyen diğer araştırmacılar, farklı sonuç ortaya koyan bu deneyin bulgularından haberdar olamayacak ve bu durum sadece araştırmacının beklediği sonucu ön plana çıkaran yanlı bir alanyazının oluşmasına neden olacaktır.

Çalışmalarda, istatistiksel analizler sonucunda elde edilebilen $p$ değerlerinin okurla paylaşılma biçimi de gizli esnekliğe sebebiyet verebilir (Wicherts vd., 2016). Başka disiplinlerde istatistiksel anlamlılı seviyesi olarak farklı $p$ değerleri temel alınabiliyor olsa da (örnek, $\mathrm{p}<.001$ ) sosyal bilimlerde genel olarak kabul gören istatistiksel anlamlılık seviyesi, $p$ değerinin .05 'ten küçük olmasıdır (Cohen, 1994). Fakat çoğunlukla .51, .60, vb. $p$ değerlerine ulaşan araştırmacılar da sonuçlarını marjinal olarak anlamlı (İng. marginally significant) şeklinde yorumlayabilmektedirler (Olsson-Collentine vd., 2019). $p$ değerini bu şekilde yorumlayıp yorumlamamak da sıklıkla araştırmacının inisiyatifine bırakılan bir başka karardır. Fakat bulguları olduğu gibi ( $p$ değeri .05 değerinden küçükse istatistiksel olarak anlamlı, büyükse anlamlı değil olarak) yansıtmak alanyazına doğru ve güvenilir bilgiler kazandırmaya katk1 sağlayabilir.

Araştırmacı serbestlik derecesi olarak alanyazında listelenen daha pek çok uygulama mevcuttur. Burada dilbilim araştırmalarında sıklıkla karşılaşılan 
durumlar özetlenmiştir. Araştırmacı serbestlik derecesi ya da diğer bir deyişle gizli esneklik, araştırmacılar tarafından özellikle kendi çıkarları doğrultusunda kullanıldığında yanlış pozitif riskini önemli ölçüde artırabilmektedir. Buna ek olarak, gizli esneklik, sakıncalı araştırma uygulamalarına yol açarak araştırmaların tekrarlanabilirliğine ve yeniden üretilebilirliğine zarar verebilmektedir (Gelman ve Loken, 2019; Simmons vd., 2011; Wicherts vd., 2016).

Sakıncalı araştırma uygulamalarının ön plana çıkan bir örneği $p$ değeri suistimalidir (İng. p-hacking). Terim ilk olarak 2012 y1lında düzenlenen bir psikoloji konferansında Uri Simonsohn tarafından alanyazına kazandırılmışırı (Aschwanden, 2019). Araştırmacıların, gizli esnekliği kötüye kullanarak araştırmalarındaki $p$ değerlerini kendi istekleri veya ihtiyaçları doğrultusunda yönlendirmeleri şeklinde tanımlanabilir. $p$ değeri suistimali yalnızca istatistiksel olarak anlamlı sonuçları seçip raporlamayı değil, anlamlı sonuç elde edene kadar örnekleme katılımc1 ekleme ya da örneklemden katılımc1 çıarma gibi durumları da kapsamaktadır (Chambers, 2017). John vd. (2012), sakıncalı araştırma uygulamalarının ne kadar yaygın olduğunu araştırdıkları çalışmada, araştırmacıların kendi itirafları ve yaygınlık tahminlerine bakarak $p$ değeri suistimalinin oldukça yaygın bir uygulama olduğunu gözlemlemiştir. $p$ değeri suistimali sonucunda birbiriyle tamamen ilgisiz iki değişken arasında dahi istatistiksel olarak anlamlı bir fark veya ilişki bulmak mümkün olabilmektedir. $\mathrm{Bu}$ sebeple, $p$ değeri suistimali, bilimsel bulguların güvenilirliğine gölge düşürmektedir (Simmons vd., 2011; Simonsohn vd., 2013).

Bir diğer sakıncalı araştırma uygulaması ise, Sonuçları Öğrenip Hipotez Kurmaktır (SÖHİK, İng. Hypothesizing After the Results are KnownHARKing). SÖHIK, bir çalışmada hipotez(ler)in sonuçlar öğrenildikten sonra oluşturulması ya da önceden belirlenmiş hipotez(ler)in sonuçların öğrenilmesinin ardından değiştirilmesine karşıllık gelir (Kerr, 1998). Bu noktada keşif çalışmaları (İng. exploratory research) ve doğrulayıcı çalışmalar (İng. confirmatory research) arasındaki ayrımdan ve bu çalışmaların dilbilim araştırmalarındaki yerinden söz etmek yerinde olacaktır. Keşif çalışmalarında araştırmacılar verideki örüntüleri gözlemleyerek bu gözlemleri açıklamak için yeni hipotezler üretmeyi amaçlamaktadır. Doğrulayıcı çalışmalardaki amaç ise, önceden oluşturulmuş hipotezleri kontrollü deneysel çalışmalar yoluyla veri toplayarak sınamaktır. Bilimdeki çoğu büyük buluş keşif analizleri sırasında verilerdeki beklenmeyen örüntüleri fark eden araştırmacılar sayesinde gerçekleşmiştir (Roettger, 2021). Öte yandan doğrulayıcı çalışmalar, hipotezleri sınayarak kuramların destekleyici bulgularla güçlendirilmesine ya da çelişkili bulgularla yeniden gözden geçirilmesine olanak tanımaktadır Doğrulayıcı çalışmalar ve keşif çalışmaları ya da aynı çalışma içinde gerçekleştirilen doğrulayıcı analizler ve keşif analizleri bilimin ilerlemesi 
anlamında birbirini tamamlayıcı niteliktedir. Sakıncalı olarak nitelendirilen SÖHİK ise, bu iki tip çalışmanın birbirine karıştırılması ve hatalı şekilde birinin diğeri gibi gösterilmesinden kaynaklanmaktadır. Yani SÖHİK, keşif niteliğindeki çalışmaların veya analizlerin doğrulayıcı nitelikteymiş gibi yansıtılmasına işaret etmektedir. Herhangi bir çalışmada hangi analizin doğrulayıcı, hangi analizin keşif amaçlı gerçekleştirildiği şeffaf şekilde belirtilmediğinde ya da veri toplandıktan sonra gerçekleştirilen keşif analizleri sanki çalışmanın tasarlanma aşamasında düşünülmüş ve doğrulamaya tabi tutulmuş gibi yansıtıldığında çarpıtılmış bir resim ortaya çıkar; bu da bilimsel bulguların geçerliliği ve güvenilirliği konusunda şüpheye neden olur (Kerr, 1998; Roettger, 2021).

Dilbilim araştırmalarında keşif çalışmalarının belirgin bir önemi vardır. Özellikle hakkında hipotez sınanacak kadar alanyazının henüz oluşmadığı dilbilimin alt alanlarında veya başka dillerde sınanmış fakat belli bir dilde ilk defa sınanacak olgular üzerine doğrulayıcı çalışma yapmak her zaman mümkün olmamaktadır. Bu da keşif çalışmalarına olan ihtiyacı artırmaktadır (örnek, Chládková ve Šimáčková, 2021; Kahraman ve Kırkıc1, 2021). Aynı zamanda, sınanacak olgu ya da dille ilgili bilgi birikiminin artabilmesi için, keşif çalışmaları aracılığıyla üretilen hipotezler doğrulayıcı çalışmalarla sınanmalı ve hangi teorinin ne ölçüde desteklendiği veya gözden geçirilmesi gerektiği saptanmalıdır. Keşif ve doğrulayıcı ayrımının net bir şekilde yapılması ve çalışma veya analizlerin raporlaştırılması aşamasında bu ayrımın açık bir şekilde belirtilmesi bulguların doğru değerlendirebilmesini sağlayacaktır.

\section{Alanyazında Listelenen Çözüm Önerileri}

Tekrarlama krizi, çekmecede kalan çalışmalar sorunu, akademik sahtekarlık gibi sorunlar araştırmacılar tarafından fark edilmiş, bu sorunlar üzerine geniş ölçekli tartışmalar gerçekleştirilmiş ve bu tartışmaları bazı çözüm önerileri izlemiştir. Ancak önerilen çözümlerin hepsinin, her alan için bütünüyle uygulanabilir olmayabileceğini belirtmek gerekir. Buna ek olarak, çözüm önerilerinin sözü edilen sorunların çözümünde başarılı olduğunu ileri sürenler olduğu gibi (Nosek vd., 2018) başarısız olduğuna dair fikir belirtenler de (Szollosi vd., 2020) mevcuttur. Tüm bu görüş farklılıklarının yanında birçok araştırmacının hemfikir olduğu konu, temel çözümün bilimsel pratiklerde şeffaf olmaktan geçtiğidir. Alanyazında listelenen ve bu bölümde bahsedilecek olan dört çözüm önerisi de temelde şeffaflığa dayanmaktadır. Ön kayıt araştırma planının araştırma gerçekleştirilmeden kaydedilip paylaşılmasını içerirken yeniden üretilebilir iş akışı araştırma sürecinin, veri/materyal paylaşımı ve ön baskı ise araştırma çıktılarının şeffaf şekilde paylaşılmasına dayanmaktadır. Çözüm önerilerini bu bakış açısıyla değerlendirerek bu çözümleri çalışılan alanın mümkün kıldığı 
ölçüde ve araştırmacıların şartlarının el verdiği kadarıyla uygulamak, daha şeffaf, yeniden üretilebilir ve tekrarlanabilir bulgulara erişmeye katkı sağlayacaktır.

\section{1 Ön Kaylt}

Alanyazında sıklıkla söz edilen çözüm önerilerinden biri ön kayıttır (İng. preregistration). Ön kayıt, bir araştırmanın planının (araştırma sorusu, verinin nasıl toplanacağı, planlanan örneklem büyüklüğ̈̈, veri analizinin ayrıntıları vb.) veri toplanmadan/araştırma gerçekleştirilmeden önce zaman mührü (İng. timestamp) eklenerek kaydedilmesidir. Eklenen zaman mührü sayesinde hangi hipotezlerin sonuçlar öğrenilmeden, hangilerinin ise sonuçlar öğrenildikten sonra ortaya konduğu görülebilmektedir. Bu sayede, sakıncalı araştırma uygulamalarından biri olan sonuçları öğrenip hipotez kurmanın (SÖHIK) önüne geçilebileceği ileri sürülmektedir (Center for Open Science, 2020; Lindsay vd., 2016; Mertzen vd., 2021; Nosek vd., 2018; Roettger, 2021). Ancak kayd1 gerçekleştiren kişi araştırmacının kendisi olduğu için ön kayıt işleminin ne zaman gerçekleştirileceği de yine araştırmacının inisiyatifine bırakılmıştır. Diğer bir deyişle, ön kayıt işleminin bir araştırmanın tüm aşamalarının tamamlandıktan sonra gerçekleştirildiği bir durumda, bu çözümün SÖHIKK uygulamalarının önüne geçmesi gibi bir işlevinden söz etmek mümkün olmayacaktır. Dolayısıyla, ön kayıtın gerçekten fayda sağlayabilmesi, araştırma planının dürüst bir şekilde, henüz uygulanmadan kaydedilmesine bağlıdır.

Ön kayıt, SÖHIK veya $p$ değeri suistimali gibi sorunlara kesin çözüm olamaması gibi çeşitli nedenlerle eleştirilse de (Devezer vd., 2021; Szollosi vd., 2020), şeffaflı̆̆ın sağlanması açısından hala faydalı görülen bir çözüm önerisidir (Mertzen vd., 2021). Ayrıca, araştırmanın temel adımları çalışma henüz gerçekleştirilmeden belirlendiği ve kayıt altına alındığı için gizli esnekliğe yol açabilecek noktaların (örnek, bağımlı-bağımsız değişkenlerin belirlenmesi, veri toplamanın ne zaman sonlandırılacağı, hangi değerlerin uç değer kabul edileceği vb.) önceden düşünülüp belirlenmesi mümkün olabilir. Ön kayıt ile ilgili temel eleştirilerden biri (Lindsay vd., 2016), ön kayıt yapmanın keşiflerin önüne geçtiği düşüncesidir. Ancak bu sav, temelinde bir yanılgıya dayanmaktadır. Bahsedilenin aksine, ön kayıt yalnızca keşif ve doğrulayıcı çalışmaları ve/veya analizleri birbirinden ayırmayı ve bunu da okurla şeffaf bir biçimde paylaşmayı teşvik etmektedir. Bu sayede, keşif çalışmalarının doğrulayıcı çalışmalarmış gibi yansıtılması önlenebilecek ve alanyazına daha güvenilir bulgular kazandırılabilecektir (Nosek vd., 2018; Roettger, 2021).

Araştırmacılar, araştırmalarının ön kayıtlarını çeşitli platformlar kullanarak gerçekleştirebilmektedir. Ön kayıt için Open Science Framework (OSF) ve Aspredicted halihazırda en yaygın olarak kullanılan platformlar olarak karşımıza çıkmaktadır. Aspredicted cevaplanması gereken dokuz adet kısa soru 
içerirken (https://aspredicted.org/), OSF'nin farklı araştırma türleri (örnek, nicel, nitel, vb.) için çeşitli ve daha ayrıntılı şablonları mevcuttur (https://osf.io/zab38/). Sorular genel olarak verinin henüz toplanıp toplanmadığı, araştırma sorusu, araştırma deseni ve veri analizleri ile ilgili ayrıntıları içermektedir.

Ön kayıtın dilbilim araştırmalarının çeşitli alt alanlarında kullanımıyla ilgili alanyazın oldukça yenidir (örnek, Havron vd., 2020; Mertzen vd., 2021; Roettger, 2021). Bu makaleler genel olarak ön kayıt uygulamalarının yanı sıra, bu uygulamalarda karşılaşılabilecek zorluklar ve kısıtlardan da söz etmektedir. Örneğin, ön kayıtın uygulamalı dilbilimde kullanımına değinen makalesinde, Roettger (2021) önceden toplanmış verilerle gerçekleştirilen derlem odaklı çalışmalarda ön kayıtın uygunluğuna dair endişeler olabileceğini öne sürmektedir. Ancak bu gibi durumlarda dahi araştırmacılar analiz planları için (veriyi analiz etmeden önce ortaya çıkabilecek olası sonuçları nasıl yorumlayacakları vb.) ön kayıt yapabilir. Analiz planlarının ön kayıt aşamasında karşılaşılabilecek önemli sorulardan birisi olarak, araştırmacının analiz öncesinde veri hakkında ne kadar bilgiye sahip olduğu gösterilebilir (örnek, derleme ne zaman eriştiği, analiz öncesi derlemdeki bilgilerden ne ölçüde haberdar olduğu vb.). Bu güçlüklerin üstesinden gelmenin temel yolu, veri analizi yapılmadan önce araştırmacının haberdar olduğu tüm bilgilerin ön kayıtı yapılan çalışma veya analiz planında şeffaf bir şekilde okurla paylaşılmasıdır. Bu sayede gizli esneklik en aza indirgenebilir.

Araştırmanın planlanma aşamasındaki birtakım belirsizlikler (kimden nasıl veri toplanacağı gibi), araştırmacıları ön kayıta karşı çekingen bir tavır almaya itebilmektedir. Bununla bağlantılı olarak, Roettger'ın (2021) dikkat çektiği bir diğer güçlük, ön kayıt üzerinde sonradan değişiklik yapılıp yapılamayacağ ${ }_{1}$ ile ilgilidir. Eriş̧ilebilmesi nispeten daha zor olan örneklemlere (örnek, afazi ya da gelişimsel disleksi tanısı almış bireyler) veya belli yaş gruplarına (örnek, bebekler, çocuklar, yaşlılar vb.) odaklanan çalışmalarda, veri toplama ve örneklem büyüklüğüne dair ayrıntıları kestirmek mümkün olmayabilir. Örneğin, dil edinimi alanında bebeklerle yapılan çalışmalarda araştırmacılar, bebeklerin huysuzluk çıkarması ya da ebeveynlerin müdahaleci tavırları gibi önceden tahmin etmesi güç sebeplerle beklenenden fazla sayıda katılımcıyı örneklemden çıkarmak zorunda kalabilir (Havron vd., 2020). Bunun yanı sıra, araştırmacılar, verilerini açıklamada anlamlı bir katkısı olmayan değişkenleri kurdukları analiz modellerinden çıkarmak gibi önceden tahmin edilemeyecek durumlarla karşı karşıya kalabilir. Pilot çalışma yapmak yaşanabilecek belirsizlikleri çalışmanın asıl verisi toplanmadan önce öngörülebilir kılmada oldukça faydalı olmaktadır. Ancak pilot çalışma asıl çalışmaya göre daha küçük bir örneklem ile gerçekleştirildiğinden olası tüm beklenmeyen durumları gözlemlemeye olanak sağlamayabilir. Bu sebeple, ön kayıtta belirtilen planda sapmalar yaşanması oldukça muhtemeldir. Şu noktanın altını çizmek gerekir 
ki, ön kayıt yapmış olmak, çalışmada değişiklik yapılamayacağı anlamına gelmemektedir. Aksine, yapılan değiş̧ikliklerin sebepleriyle birlikte şeffaf bir biçimde okurla paylaşılması, çalışmaya duyulan güveni artıracaktır (Lindsay vd., 2016).

Bir araştırma konusu hakkında somut tahminlerde bulunmak her zaman mümkün olmayabilir. Örneğin, halihazırda gelişmekte olan bir alanda çalışmalar yapan araştırmacılar için hipotez oluşturmak veya bu hipotezlerle ilgili tahminlerde bulunmak kolay olmayabilir. Böyle durumlarda araştırmacılar, keşif çalışmaları yürütebilir ve bu çalışmalar aracılığıyla daha sonra sınanmak üzere yeni hipotezler ortaya koyabilirler. Keşif çalışmalarının gideceği yön net bir biçimde belli olmadığı için, ön kayıt bu tür çalışmalarda kullanmak için uygun bir çözüm yöntemi değilmiş gibi görünebilir. Ancak gizli esnekliğin yol açabileceği sorunları en aza indirmek ve şeffaflığı azami seviyeye çıkarmak için, doğrulayıcı çalışmalardaki kadar olmasa da, ön kayıt keşif çalışmaları için de önemli bir çözüm önerisi olarak görülmektedir (Roettger, 2021; keşif çalışmalarında ön kayıt için bkz. Dirnagl, 2020). Tüm bunların yanında, ön kayıt temelde deneysel ve hipotez sınayan çalışmalar için tasarlanmış olduğundan, ön kayıt yapmak dilbilimin her bir alt alanında (örnek, söylem çözümlemesi, tarihsel dilbilim vb.) uygulanması mümkün ya da faydalı olmayabilir. Bu sebeple, alanyazında önerilen ön kayıtı uygulanması zorunlu ya da sorunlara kesin çözüm getirecek bir yöntem gibi algılamak yerine, çalışılan alana bağlı olarak uygulanabilecek ve çalışmaların şeffaflığını artırabilecek bir çözüm önerisi şeklinde değerlendirmek daha sağlıklı olacaktır (Roettger, 2021).

Ön kayıt ile ilgili endişelerin ve soru işaretlerinin yanı sıra, dilbilim araştırmalarının alt alanlarında bu uygulamanın ne tür faydalar sağlayacağına değinen makaleler de mevcuttur. Örneğin, Mertzen vd. (2021) hipotez sınamaya dayalı ikidillilik çalışmalarında ön kayıtın, veri paylaşımı ve analiz kodu paylaşımıyla birlikte kullanılmasının önemini vurgulamaktadır. Tıpk1 psikoloji alanında olduğu gibi, dilbilim alanında ikidillilik çalışmalarında da hipotez ve veri analizi ile ilgili ayrıntıların veri toplanmadan önce belirlenmemesi ve materyal/verilerin okurla doğrudan paylaşılmaması gibi sorunların varlığından bahsedilmektedir (Marsden vd., 2017). Dolayısıyla, ön kayıtın diğer deneysel alanlarda olduğu gibi, ikidillilik araştırmalarında da şeffaflı̆̆g 1 artıracağı öne sürülmüştür. Mertzen vd. (2021) ayrıca ikidillilik çalışmalarında sakıncalı araştırma uygulamalarının önüne geçebilmek için, burada listelenen ve benzeri ayrıtıların ön kayıt belgesinde bulunması gerektiğini vurgulamıştır: Araştırma sorusu, hipotezler, çalışma deseni, yöntem, katılımcı seçme ölçütleri, veri toplama süreci, örneklem büyüklüğü, veri toplamanın ne zaman sonlandırılacağı, analiz planı (örnek, uç değer, istatistiksel model, veri çıkarma ölçütleri). 
Ön kayıt sistemi, bağımsız hakem değerlendirmesi gibi bir süreçten geçmediği için belge doldurulurken ne kadar ayrıntı verileceği de araştırmacıların inisiyatifine kalmaktadır. $\mathrm{Bu}$ nedenle alanyazında altı çizilen nokta, ön kayıtın ancak olabildiğince ayrıntılı bir araştırma planı içeren ve bu planda yaşanan sapmaların sebeplerinin açıkça belirtildiği halinin şeffaflığı ve yeniden üretilebilirliği artırabileceği görüşüdür (Mertzen vd., 2021). Bu denli ayrıntılı bir planı çalışmayı gerçekleştirmeden önce hazırlamak her ne kadar zahmetli olsa da, çalışmanın ileri aşamalarındaki belirsizlikleri büyük ölçüde ortadan kaldırdığı için geleceğe iyi bir yatırım olarak düşünülebilir (Lindsay vd., 2016). Ayrıca araştırmacıyı, çalışmasını gerçekleştirmeden önce araştırmasıyla ilgili tüm ayrıntıları ve olasılıkları düşünmeye teşvik ettiği için ön kayıtın çalışmaların kalitesini artırıcı bir rolünden de söz etmek mümkündür (Havron vd., 2020). Buna rağmen önemle belirtmek gerekir ki ön kayıtın hatalı araştırma soruları barındıran veya hatalı yöntemler üzerine kurulan çalışmaların düzeltilmesi konusunda faydalı olamayacağı çeşitli makalelerde vurgulanmıştır (Havron vd., 2020; Szollosi vd., 2020).

Diğer yandan, çözüm olarak esasen hipotez sınayan nicel çalışmalar için önerilmiş ön kayıtın, nitel çalışmalarda da kullanılıp kullanılamayacağı son yıllarda tartışma konusu olmuştur (Haven ve Van Grootel, 2019). Dilbilim çalışmalarının önemli bir kısmının nitel çalışmalardan oluştuğu düşünüldüğünde, ön kayıt ve ilgili tartışmaların nitel çalışmalar boyutunda da ele almak yerinde olacaktır. Nitel çalışmalarda araştırma soruları, hatta çalışmanın deseni dahi elde edilecek veriye bağlı olarak değişebildiğinden ve sonuçların yorumu da belli bir ölçüde araştırmacının öznel değerlendirmesine dayandığından, ön kayıt yapmanın bu çalışmalarda pek mümkün olmadığı öne sürülmektedir (Haven ve Van Grootel, 2019). Ancak bu görüşe karşılık, Haven ve Van Grootel (2019) ön kayıt yapmanın nitel çalışmaların şeffaflığını artırmada faydalı olacağını savunmaktadır. Nitekim nitel çalışmalarda çoğunlukla bir hipotezin sınanmaması yahut doğası gereği araştırmacılara daha fazla serbestlik derecesi sağlıyor oluşu, bu çalışmalarda da şeffaflığın gözetilmesi gerektiği gerçeğini değiştirmemektedir. Nicel çalışmalarda olduğu gibi, nitel çalışmalarda da ön kayıt yapılan planda değişiklikler yapmak mümkündür. Hatta nitel çalışmalarda doğal olarak bu değişikliklerin daha fazla olacağı öngörülebilir.

Yukarıdaki açıklamalardan yola çıkarak Haven ve Van Grootel (2019) nitel çalışmalarda kullanılacak ön kayıt şablonunun, nitel çalışmaların doğasına uygun soruları içeren ve gelişmelerin/değişikliklerin okurla devamlı olarak paylaşılmasını mümkün kılan bir formatta olması gerektiğini savunmuştur. Bu şablon türünün, nitel bir çalışmanın planının yalnızca ilk haline değil, güncellemelerin yer aldığ1 her bir sürümüne erişebilmeyi sağlayacağ1 vurgulanmıştır. Bu sayede okurlar çalışma planında yaşanan sapmalar, bunların nedenleri ve veriyi yorumlama sürecinin nasıl ilerleyeceği hakkında fikir sahibi 
olabilecektir. Ayrıca, araştırmacının çalışılan konuya hangi çerçeveden yaklaştığı, konunun kişisel değerleriyle ne ölçüde ilintili olduğu ve bu bağlantıların sonuçların yorumlanmasına nasıl etki edebileceği gibi önemli ayrıntılar da ön kayıta dahil edilebilir. Dolayısıyla, ön kayıt okurlar ve diğer araştırmacıların veri analizi ve yorumlanma süreçlerinin değerlendirilmesine olanak sağladığından (örnek, araştırma sorusu, kullanılan yöntemin uygunluğu, veriyi yorumlamadaki öznellik vb.) nitel çalışmalarda güvenilirliği artıran bir unsur olarak da görülebilir.

Özetle, ön kayıt sakıncalı araştırma uygulamaları için kesin bir çözüm olarak değerlendirilemeyebilir ve dilbilim araştırmalarının her alt alanı için de aynı ölçüde kullanışlı olmayabilir. Ancak yukarıda da vurgulandığı gibi, ön kayıt şeffaflı̆̆ın sağlanması konusunda oldukça önemli bir role sahiptir. Ayrıca araştırma planının önceden ayrıntılı bir şekilde düşünülmesini teşvik ettiği için, ön kayıt araştırmacıların çalışmalarını daha özenli bir biçimde yürütebilmelerine katkı sağlayan faydalı bir uygulamadır.

\subsection{Yeniden Üretilebilir İş Akışı}

Yeniden üretilebilirliği sağlayabilmek için, bir araştırmacının araştırma süresince izlediği yolları şeffaf bir biçimde okurla paylaşması büyük önem taşımaktadır. Okur ancak tüm süreci takip edebildiğinde çalışmanın veya çalışmadan elde edilen sonuçların tekrarlanabilirliği/güvenilirliği hakkında nesnel bir değerlendirme yapma şansı elde edecektir. Yeniden üretilebilirlik, daha önce de bahsedildiği gibi, dilbilim araştırmaları için oldukça önemlidir ve yeniden üretilebilirliğin dilbilim araştırmalarında bilimsel özeni sağlama, bulgulara olan güveni artırma ve tekrar çalışmalarına zemin hazırlama konularında kilit bir role sahip olduğu görülmektedir. Bununla bağlantılı olarak, Christensen vd. (2019) sosyal bilimlerde şeffaf ve yeniden üretilebilir araştırmalar yapabilmek için izlenecek iş akışıyla ilgili bazı önerilerde bulunmuştur. Öncelikle, iş akışının hangi içerikleri kapsadığına değinen yazarlar, bu sürecin dosyaları adlandırma, klasörleri düzenleme, toplanan veriyi saklama ve yeniden üretilebilir programlama kodları/komutları oluşturma olmak üzere temelde dört farklı unsurdan oluştuğunu belirtmiş̧tir. Makalede üzerinde durulan öneriler bu dört unsurla uyumlu şekilde sunulmuştur. Bu önerilerden bazıları, nicel ya da nitel fark etmeksizin, dilbilim araştırmalarının hemen her bir alt alanında rahatlıkla kullanılabilecek özelliktedir. Bu sebeple, sözü edilen bu öneriler, mevcut makale kapsamında takip eden paragraflarda tartışılmıştır.

Önerilerin ilki, araştırmayla ilgili dosyaları adlandırırken kullanılan adlandırma yöntemiyle ilgilidir. Araştırmacıların birçoğu, dosya adına 'final' veya 'son' gibi sözcükler ekleyerek dosyalarını adlandırmayı tercih edebilmektedir. Ancak bu alışkanlık, başta araştırmacının kendisi için geçerli olmak üzere, diğer araştırmacılar ve okurlar araştırmayı incelerken hangi 
dosyanın ne içerdiği ile ilgili bir karmaşaya ve yeniden üretilebilirliğin azalmasına sebep olabilir. Christensen vd. (2019) bu duruma çözüm olarak araştırmacıların dosyalarını şu şekilde adlandırmalarını önermektedir: Tarih + Araştırmacının Ad-Soyad Baş Harfleri veya Dosyanın Sürüm Numarası. Belirli bir araştırma dosyasında yapılan değiş̧iklikleri, değişikliklerin kimler tarafından ve ne zaman yapıldığı gibi ayrıntıları gösteren bir yöntem olan sürü̈m kontrolü (İng. version control) de bu tür karışıklıkların önüne geçmek amacıyla kullanılabilir. Sürüm kontrolü, yeniden üretilebilirliğe katkısının yanında, ortak çalışmaların başarılı bir şekilde yürütülebilmesi için de oldukça önem taşımaktadır. Bu sayede, ortak çalışma yürüten araştırmacılar birbirlerinin yaptı̆̆ 1 değişikliklerden tüm ayrıntılarıyla haberdar olabilmektedir (Bowers, 2011). Git (https://git-scm.com/), Simul (https://www.simuldocs.com/) ve OSF (https://osf.io/), sürüm kontrolü için kullanılabilecek platformlara örnek gösterilebilir.

Yukarıdakilere ek olarak, Christensen vd. (2019), araştırma klasörlerinin düzenlenmesi konusunda da çeşitli öneriler sunmaktadır. Örneğin, çalışmanın çeşitli aşamaları ve çıktıları için (örnek, ham veri, analiz, makale yazımı) ayrı klasörler oluşturmak ve tüm bu klasörleri de bir ana klasör içerisine yerleştirmek, ileride araştırmacılara aradıkları dosyaları kolayca bulabilme olanağı sağlayacaktır. Bu durum, aranan dosyaların bulunma sürecini başka araştırmacılar için kolaylaştıracağından, klasörlerin bu şekilde düzenlenmesi yeniden üretilebilirlik için önemlidir. Dahası, oluşturulan ana klasör içine ek olarak bir beni oku (İng. readme) dosyası eklemek ve bu dosyaya klasördeki her bir dosyanın ne içerdiğini belirten notlar yazmak hem araştırmacının kendisine hem de çalışmayı/bulguları yeniden üretmek isteyebilecek diğer araştırmacılara büyük kolaylık sağlayacaktır (Bowers, 2011). Ham veriyi korumak ve analiz esnasında oluşabilecek sorunları daha kolay çözmek adına, ham veri dosyası üzerinde doğrudan değişiklik yapmamak ve değişiklik yapılacaksa bunu ayrı bir dosya olarak kaydetmek dikkate değer bir öneri olarak karşımıza çıkmaktadır.

Araştırmalarda log dosyası (İng. log file) tutmak, araştırma grubunda kimin hangi değişikliği/güncellemeyi ne zaman yaptığını belirlemeye yardımcı olarak yeniden üretilebilirliği artırabilir. Veri analizinde ulaşılan sonuçla beraber izlenen aşamaların (örnek, kullanılan kod, araştırmacının izlediği yolla ilgili açıklamaları ve yorumları vb.) okurla paylaşılması hem şeffaflık hem de yeniden üretilebilirliği artırabilecek önemli bir öneridir. Bu sayede diğer araştırmacılar aynı aşamaları takip ederek aynı sonuca ulaşıp ulaşamayacaklarını rahatça sınayabilirler (Bowers, 2011).

Yeniden üretilebilir analizler için nicel çalışmalarda JASP (https://jaspstats.org/) ve Jamovi (https://www.jamovi.org/) programları kullanılabilir. Bu programlar, açık kaynak kodlu ve ücretsiz olmalarının yanı sıra, araştırmacılara yapılan analizler için açıklama ve yorum ekleme olanağı sunmaktadır. Bu not 
ekleme işlevi sayesinde, analiz dosyalarını inceleyen herhangi bir araştırmacı, analizi gerçekleştiren kişinin hangi adımları izlediği, hangi gerekçelere dayanarak bu adımları tamamladığı gibi bilgilere kolaylıkla erişebilmektedir. Şeffaflığı ve özellikle yeniden üretilebilirliği destekleyecek bir diğer öneri de kullanılan veri analizi programının/paketinin sürüm numarasının okurla paylaşılması olabilir. $\mathrm{Bu}$ durum, başta çok önemli bir ayrıntı gibi görünmeyebilir, ancak sürüm farkı sebebiyle yeniden üretilebilirliği sınanan analizlerdeki kodların, başka bilgisayarlarda düzgün bir şekilde çalışmaması gibi istenmeyen durumlar yaşanabilmektedir. $\mathrm{Bu}$ ve benzeri sorunlarla karşılaşmamak adına, diğer araştırmacıların sürüm numarası bilgisine erişebilmesi ve analizleri aynı sürüm üzerinden tekrarlayabilmesi büyük önem taşımaktadır. Christensen vd. (2019) yukarıda bahsedilen önerilere ek olarak, bir araştırmaya dair tüm dosyaların yedeklenmesinin önemini vurgulamaktadır.

\section{3 Ön Baskl}

OSF'nin internet sitesinde ön baskı (İng. pre-print), bilimsel bir makalenin hakem değerlendirmesine girmeden önce okurla halka açık bir şekilde paylaşılan son taslağ 1 olarak tanımlanmaktadır. Ancak hakem değerlendirmesinden geçerek yayına uygun görülmüş makalelerin son şekli yazar tarafindan verilmiş (İng. author-formatted) olmak kaydıyla, ön baskı olarak paylaşıldı̆̆ da görülmektedir (Moshontz vd., 2021). Ön bask1 paylaşımı için OSF'ye ek olarak, farklı alanlardaki araştırmacılar tarafindan kullanılan çeşitli platformlar (örnek, fizik: ArXiv; yaşam bilimleri: BiorXiv; psikoloji: PsyArXiv, sosyal bilimler: SocArXiv vb.) mevcuttur. LingBuzz (https://ling.auf.net/) gibi platformlar bulunmasına rağmen, dilbilim araştırmalarına özel yaygın kullanılan bir ön baskı platformu henüz mevcut değildir. Dolayısıyla, dilbilim araştırmacılarının genelde platform tercihini ön baskısını paylaşacakları makalenin mahiyetine göre yaptıkları söylenebilir. Ön baskı, halka açık bir şekilde paylaşıldığında hem alanyazının kalıcı bir parçası olmakta hem de kendine özgü dijital nesne tanımlayıcıs (İng. digital object identifier, DOI) sayesinde atıf verilebilir hale gelmektedir. Ayrıca, ön baskılar düzenleme ve güncellemeye açı belgeler olarak düşünülebilir. Yukarıda sözü edilen ön bask1 yükleme platformları incelendiğinde, karşılaşılan örneklerin birçok kez güncellendiği ve ön baskısı yapılan makalenin tüm versiyonlarına okurlar tarafından erişilebildiği gözlemlenebilir.

Mudrak (2020), American Journal Experts adındaki internet sitesindeki yazısında ön baskının faydalarına değinmiştir. Bilim camiasından hızlı geri dönüt alma firsatı sunması bu faydalardan biri olarak örnek gösterilebilir. Ayrıca, hakem değerlendirme sürecinin aylar hatta bazen yıllar sürebildiği göz önüne alındığında, ön baskılar sayesinde bilimsel çıktıların çok daha hızlı bir şekilde yayılması söz konusu olabilir (Moshontz vd., 2021). Ön baskının bir 
diğer faydası ise, eklenen zaman mührü (ilk ne zaman yüklendiği ve en son ne zaman düzenlendiği bilgisi) sayesinde keşiflerde belli bir bulguyu ilk kimin ortaya koyduğunu belirlemeye yardımcı olmasıdır. Ancak tüm bu faydalarının yanında, ön baskıların, genelde bilimsel makalelerin hakem değerlendirme sürecinden geçmeden veya herhangi bir dergide yayımlanmadan önceki sürümleri olduğu göz önünde bulundurulmalıdır. Bu nedenle, ön baskılarda rapor edilen bulguların bu çerçevede değerlendirilmesi daha yerinde olacaktır.

\subsection{Veri ve Materyal Paylaşımı}

Veri ve materyal paylaşımı bilimsel çalışmalarda şeffaflığı ve yeniden üretilebilirliği artıran çözüm önerileri arasında yer almaktadır. Araştırmacıların araştırma sonuçlarını dayandırdıkları verilerin diğer araştırmacılar tarafından erişilebilir olması, bilimsel hesap verebilirliği güçlendirdiği gibi, bunun doğal sonucu olarak yeniden üretilebilirliğe katkı sağlayan önemli bir unsur olarak değerlendirilebilir (Berez-Kroeker vd., 2018). Bilimsel bir çalışma yayımlanmasının ardından iki nedenle bu araştırmanın verisine ihtiyaç duyulabilir. Bunlardan birincisi, ortaya konan bulguyu doğrulamayı ya da güvenilirliğini artırmayı kapsayan, değerlendirme odaklı nedenlerdir. Diğer bir neden, başka araştırmacılara, paylaşılan veriyi inceleyerek yeni araştırma soruları üretme olanağı sağlaması gibi üretim odaklı nedenler olarak gösterilebilir (Christensen vd., 2019).

Öte yandan, araştırmacılar verilerini paylaşmaya gönüllü olmayabilirler. Veri paylaşımına karşı bu isteksiz tutumun, araştırmacıların elde ettikleri kanıtı yeterince güçlü görmediklerinden kaynaklanıyor olabileceği öne sürülmüştür. Analiz esnasında veya sonuçlar rapor edilirken yapılmış ciddi hataların, verilerin başka araştırmacılar tarafından yeniden analiz edilmesiyle ortaya çıkabileceği gerçeği, araştırmacıları temelinde korku ve endişe barındıran bu tutumu takınmaya itiyor olabilir (Wicherts vd., 2011).

Özellikle veriye bağlı olarak araştırma sorularının üretildiği nitel çalışmalarda, araştırmacılar verileriyle işleri tam olarak bitmediğinde, bu verileri başkalarının kullanımına açmak için bir süre beklemeyi tercih edebilirler. Bu gibi durumları ilgilendiren çeşitli çözüm önerileri veri paylaşımı ile ilgili alanyazında listelenmiştir. Örneğin, araştırmacıların verinin tamamı yerine, yeniden üretilebilirliği sağlamak adında yalnızca makalede temel alınan ilgili kısımlarını paylaşmak gibi bir seçeneğinin de olduğu vurgulanmaktadır (Christensen vd., 2019). Ancak verinin tamamı paylaşılmadığı için, bu çözüm, sınanmış ama anlamlı etkisi olmadığı için okurdan gizlenmiş değişkenlerin neden olabileceği sorunların önüne geçilmesi konusunda etkili olmayabilir. Böyle bir senaryoda ön kayıtın önemi kendini daha da belirgin bir şekilde göstermektedir. Ön kayıt sayesinde verinin paylaşılan kısmı için hangi değişkenlerin analiz planına dahil edildiği bilgisine ulaşmak mümkün olabilir. 
Veri paylaşımı endișelerini giderebilecek bir diğer çözüm ise veriye ambargo koymaktır. $\mathrm{Bu}$ durumda veri belirli bir veri havuzunda paylaşılır, ancak araştırmacı, verinin halka açık paylaşımı için bir süre kısıtlaması getirir. Başka bir deyişle, veri ancak belirlenen süre geçtikten sonra halka açı hale gelebilir ve araştırmacılar bu süre içerisinde veriyle ilgili akıllarındaki soruları gidermek için firsat elde etmiş olur. Tüm bunlara ek olarak, paylaşılan verilere de atıf yapmak mümkün olmaktadır (Christensen vd., 2019). Paylaşılan veriden faydalanan diğer araştırmacıların makalelerinde bunu kaynak göstermesi gerekeceğinden, bu durumun veri paylaşımına karşı takınılan olumsuz tutumları azaltabileceği düşünülebilir. Bir çalışmanın verisine atıf verirken çeşitli biçemler (örnek, APA, MLA, vb.) kullanmak mümkündür. Biçemlere göre farkl111klar olsa da temelde veriye atıf verirken verinin sahibi (kişi veya kurum), veri setinin ismi, yılı, sürüm numarası, verinin yer aldığ 1 web sayfasının ismi ve verinin türü (örnek, ham veri, analiz kodu, anket verisi vb.) gibi bilgiler belirtilmektedir (https://dataverse.org/best-practices/academiccredit).

Veri paylaşımı konusunda vurgulanması gereken başka bir nokta da paylaşım yapılmadan önce verideki katılımcıların kimliklerinin saptanmasına yol açabilecek her türlü bilginin anonim hale getirilmesi gerektiğidir. Yine de bazı bilgileri anonim hale getirmenin sorunu çözmediği durumlar yaşanabilmektedir. Örneğin, verinin toplandığ 1 yer az çok tahmin edilebiliyorsa, diğer birtakım bilgiler bir araya getirildiğinde (yaş + cinsiyet + öğrenim durumu + doğum yeri) katılımcılardan bazılarının tespit edilmesi mümkün olabilir. Bu tür durumların önüne geçmek için, veri setine gürültü (İng. noise) eklemek bir çözüm önerisi olarak değerlendirilebilir (Christensen vd., 2019). Diğer bir deyişle, kimlik saptanmasında önemli role sahip değişkenler için katılımcıların bilgilerini doğrudan paylaşmak yerine, daha genel ifadeler kullanarak veri halka açık hale getirilebilir. Örneğin, katılımcıların konuştuğu ikinci yabancı dili 'İngilizce' şeklinde belirtmek yerine 'Hint-Avrupa Dili' ifadesini kullanmak, kimlik saptama durumunu güçleştirebilir. Verideki bilgileri anonim hale getirmenin sorunu çözmediği hassas durumlarda veri paylaşımının güvenilir bir seçenek olup olmadığ hususunda, başta üniversitelerin etik komiteleri olmak üzere gerekli kişilere danışılması büyük önem arz etmektedir.

Araştırmacılara veri paylaşımı için genel olarak kendi internet sitelerini değil, yüksek kalitedeki veri arşiv platformlarını kullanmaları önerilmektedir. $\mathrm{Bu}$ sayede, internet sitesinin çökmesi ya da kapanması gibi durumlarda verinin kaybedilme ihtimali en aza indirgenebilir. Veri paylaşımı için Dataverse (King, 2007), OSF, Zenodo (European Organization For Nuclear Research \& OpenAIRE, 2013) gibi platformlar mevcuttur. Ayrıca, dilbilim araştırmaları için özel olarak bu alana odaklanan ve açı erişime sahip TROLLing (https://dataverse.no/dataverse/trolling) platformu da bir seçenek olarak 
düşünülebilir. Derlem verisinden deneysel veriye birçok farklı dilsel veri seti ve analiz koduna bu platformdan erişmek mümkündür. Dahası, bu platform aracılığıyla dilbilim alanında yürütülmüş bazı tekrar çalışmalarına ait verilere de erişilebilmektedir.

Veri paylaşımı kadar materyal paylaşımı da tekrar çalışmalarının yapılabilmesi, şeffaflığın ve yeniden üretilebilirliğin sağlanabilmesi için önemli bir role sahiptir. Materyal paylaşımı için dilbilim araştırmalarında, özellikle de ikinci dil araştırmalarında IRIS platformu (https://www.irisdatabase.org/iris/app/home/index) sıklıkla kullanılmaktadır. $\mathrm{Bu}$ dijital veri havuzunda ikinci dil araştırmalarında kullanılan materyal ve görevler (örnek, sözcüksel karar, kendi hızında okuma, çeviri, dilbilgisel yargı) ücretsiz ve herkese açık şekilde başka araştırmacıların kullanımına sunulmaktadır (Marsden vd., 2017). Bazı durumlarda (örnek, nispeten daha eski zamanlı makalelerde) araştırmalarda kullanılan görev ve materyaller hakkındaki bilgilere erişmek mümkün olmayabilir. Böyle bir durumda, araştırma bulgularının tekrar edilebilirliğini sınamak gibi bir durumdan söz etmek oldukça zor olacaktır. Yukarıda sözü edilen bu platformlar sayesinde, bilimsel araştırmalarda kullanılan görev ve materyallere erişim sağlanabildiğinde, tekrar çalışması yapmayı planlayan araştırmacılara büyük kolaylık sağlanmış olacak ve bilimsel araştırmaların tekrar edilebilirliği de artacaktır.

Berez-Kroeker vd. (2018), dilbilimde yeniden üretilebilirliğin artması için veri toplama ve veri analizi aşamalarında kullanılan yöntemlerin yanı sıra, toplanmış kaynak veri hakkındaki ayrıntıların da şeffaf bir şekilde paylaşılması gerektiğinin altını çizmektedir. Veri toplama ve veri analizinde kullanılan yöntemlerde şeffaf olmak, (a) verinin hangi vasıta ile toplandığı, (b) verinin nerede toplandığı, (c) bu sürecin ne kadar sürdüğü, (d) katılımcı profili ve (f) analiz ayrıntıları gibi unsurların açıkça bildirilmesini kapsamaktadır. Kaynak verinin paylaşımında şeffaflığı arttırmak ise verinin doğası (örnek, derlem verisi, yayımlanmış veri, deneysel veri vb.), veriye nereden ulaşılabileceği (örnek, veri havuzu, arşiv vb.) veya sadece bir kısmından faydalanılan verilerde, verinin ilgili kısmının neresi olduğu (örnek, sayfa numarası, derlemdeki satır numarası, ses/görüntü kaydında dakika bilgisi vb.) gibi bilgilerin paylaşılmasını gerektirmektedir.

Dilbilimde bu şeffaflığın ne ölçüde sağlandığıyla ilgili olarak, dilbilim araştırmalarında kendilerine yeterince bilgi verilmemesinden dolayı, genelde okurların araştırma ayrıntıları hakkında kendi çıkarımlarını üretmek zorunda kaldıkları gözlenmiştir (Berez-Kroeker vd., 2018). Bu da alandaki çalışmalara olan güveni azaltabilmektedir. Öte yandan, dilbilim araştırmalarının birçok alt alanında şeffaflığı arttırmaya dair çabaların öne çıkmakta olduğu vurgulanmıştır. Örneğin, Berez-Kroeker vd. (2018), ikinci dil edinimiyle ilgili Studies in Second Language Acquisition dergisinde yayın yapan yazarların, araştırma yöntemlerine dair ayrıntıları aktarmada oldukça şeffaf 
davrandıklarını rapor etmiştir. Ayrıca, yine bu makalede sözü edilen ve sesbilgisi araştırmalarını yayımlayan dergilerde kullanılan araç, donanım ve yazılım konusunda araştırmacıların şeffaf paylaşım eğilimi gösterdikleri aktarılmıştır. Dilsel verilerin dilbilim araştırmalarının temelini oluşturduğu düşünüldüğünde, bu alanda çalışmalar yürüten araştırmacıların, verilerin belgelenmesi, saklanması ve alıntılanması konusunda sorumluluk alması önem taşımaktadır. Verilerin erişilebilir bir yerde saklanması, yeniden kullanılabilmesi ve veriye atıf yapılabilmesi konusunda gerekli ölçütlerin belirlenmesi/benimsenmesi, şeffaflık ve yeniden üretilebilirliğin alanda azami seviyeye çıkarılmasında kilit rol oynayacaktır (Berez-Kroeker vd., 2018).

\section{Sonuç}

Bu makale, tekrarlama krizi, bilimsel sahtekarlık ve yayın yanlılı̆̆ gibi açık bilime zemin hazırlayan sorunlar üzerine güncel tartışmalardan yola çıkarak şeffaflık, yeniden üretilebilirlik ve tekrarlanabilirlik kavramlarının dilbilim araştırmalarında nasıl kendini gösterebileceğine odaklanmıştır. Buradan hareketle, gizli esneklik ve sakıncalı araştırma uygulamaları kapsamında değerlendirilen uygulamalar, dilbilim araştırmaları özelinde örneklendirilmiş ve makalede çalışmaların güvenilirliğine zarar verebilecek bu sakıncalı uygulamalara karşı bir farkındalık oluşturmak hedeflenmiştir. Dahası, alanyazında listelenen ve bu makalede sözü edilen çözüm önerilerinin (ön kayıt, yeniden üretilebilir iş akışı, ön baskı ve veri/materyal paylaşımı) hepsinin temelde şeffaflı̆̆ 1 sağlamayı amaçladığı görülmektedir. Ancak bu çözüm önerilerinden bazılarının, dilbilim araştırmalarının her bir alt alanı için kullanıma uygun olmayabileceği göz önünde bulundurulmalıdır. Belki daha da önemlisi, çözüm önerilerinin uygulama kolaylığı da birbiriyle aynı değildir ve aynı çözüm, farklı alanlarda farklı derecede iş yükü gerektirebilir (Kathawalla vd., 2021). Örneğin, ön baskı kısa bir sürede tamamlanabilirken, ön kayıt araştırmacılar için birçok aşamanın hesaba katıldığı zaman alıcı bir süreç haline gelebilir (Kathawalla vd., 2021). Ayrıca, ön kayıtta izlenen yol nitel ve nicel çalışmalarda doğal olarak farklılık gösterecektir. Araştırmacıların, tüm olası sorun ve çözümleri kendi eleştirel süzgeçlerinden geçirerek değerlendirmeleri önerilmektedir. Şeffaflık, yeniden üretilebilirlik ve tekrarlanabilirlik ilkelerinin, dilbilimin her bir alt alanında tartışılmasının, bu ilkelerin dilbilim araştırmacıları için bir araştırma kültürü haline gelmesine büyük katkı sağlayacağı aşikardır. Araştırmacıların, tartı̧ılan bu çözümleri ellerinden gelen en iyi şekilde uygulamaları ve kendi alanlarına özgü yeni çözüm önerileri düşünüp üretmeleri, dilbilim alanını daha da ileriye götürecektir. 


\section{Kaynaklar}

Aschwanden, C. (2019). We're all "p-hacking" now. Wired. https://www.wired.com/story/were-all-p-hacking-now/

Aygen, G. (2012). Morpho-syntactic variation and methodology. Dil ve Edebiyat Dergisi, $8(1), 1-14$

Berez-Kroeker, A. L., Gawne, L., Kung, S. S., Kelly, B. F., Heston, T., Holton, G., Pulsifer, P., Beaver, D. I., Chelliah, S., Dubinsky, S., Meier, R. P., Thieberger, N., Rice, K., \& Woodbury, A. C. (2018). Reproducible research in linguistics: A position statement on data citation and attribution in our field. Linguistics, 56(1), 1-18. https://doi.org/10.1515/ling-2017-0032

Bowers, J. (2011). Six steps to a better relationship with your future self. The Political Methodologist, 18(2), 2-8.

Camerer, C. F., Dreber, A., Forsell, E., Ho, T.-H., Huber, J., Johannesson, M., Kirchler, M., Almenberg, J., Altmejd, A., Chan, T., Heikensten, E., Holzmeister, F., Imai, T., Isaksson, S., Nave, G., Pfeiffer, T., Razen, M., \& Wu, H. (2016). Evaluating replicability of laboratory experiments in economics. Science, 351(6280), 1433-1436. https://doi.org/10.1126/science.aaf0918

Center for Open Science. (2020). Preregistration. https://www.cos.io/initiatives/prereg

Chambers, C. (2017). The seven deadly sins of psychology. Princeton University Press; JSTOR. https://doi.org/10.2307/j.ctvc779w5

Chládková, K., \& Šimáčková, Š. (2021). Distributional learning of speech sounds: An exploratory study into the effects of prior language experience. Language Learning, 71(1), 131-161. https://doi.org/10.1111/lang.12432

Christensen, G., Freese, J., \& Miguel, E. (2019). Transparent and reproducible social science research (1. bs). University of California Press; JSTOR. https://doi.org/10.2307/j.ctvpb3xkg

Cohen, J. (1994). The earth is round ( $\mathrm{p}<.05)$. American Psychologist, 49(12), 997-1003. https://doi.org/10.1037/0003-066X.49.12.997

Coretta, S. (2020). Open Science in phonetics and phonology [Preprint]. Open Science Framework. https://doi.org/10.31219/osf.io/4dz5t

Crüwell, S. (2019). Seven easy steps to open science: An annotated reading list. Zeitschrift Für Psychologie, 227(4), 237-248. https://doi.org/10.1027/2151-2604/a000387

Devezer, B., Navarro, D. J., Vandekerckhove, J., \& Ozge Buzbas, E. (2021). The case for formal methodology in scientific reform. Royal Society Open Science, 8(3), 200805. https://doi.org/10.1098/rsos.200805

Dirnagl, U. (2020). Preregistration of exploratory research: Learning from the golden age of discovery. PLOS Biology, 18(3), e3000690. https://doi.org/10.1371/journal.pbio.3000690

European Organization For Nuclear Research \& OpenAIRE. (2013). Zenodo. CERN. https://doi.org/10.25495/7GXK-RD71

Ferguson, C. J., \& Heene, M. (2012). A vast graveyard of undead theories: Publication bias and psychological science's aversion to the null. Perspectives on Psychological Science, 7(6), 555-561. https://doi.org/10.1177/1745691612459059

Franco, A., Malhotra, N., \& Simonovits, G. (2014). Publication bias in the social sciences: Unlocking the file drawer. Science, 345(6203), 1502-1505. https://doi.org/10.1126/science.1255484 
Gelman, A., \& Loken, E. (2019). The garden of forking paths: Why multiple comparisons can be a problem, even when there is no "fishing expedition" or "p-hacking" and the research hypothesis was posited ahead of time. 17.

Haven, T., \& Van Grootel, Dr. L. (2019). Preregistering qualitative research. $\begin{array}{llll}\text { Accountability in } & \text { Research, }\end{array}$ https://doi.org/10.1080/08989621.2019.1580147

Havron, N., Bergmann, C., \& Tsuji, S. (2020). Preregistration in infant research-A primer. Infancy, 25(5), 734-754. https://doi.org/10.1111/infa.12353

Hoekstra, R., \& Vazire, S. (2020). Hoekstra \&amp; Vazire (2020), Intellectual humility is central to science [Preprint]. PsyArXiv. https://doi.org/10.31234/osf.io/edh2s

Hui, B., \& Huntley, E. (2020). Embracing open science in applied linguistics: Graduate students' perspectives [Ön Bask1]. Open Science Framework. https://doi.org/10.31219/osf.io/vmtza

Ioannidis, J. P. A. (2005). Why most published research findings are false. PLoS Medicine, 2(8), e124. https://doi.org/10.1371/journal.pmed.0020124

John, L. K., Loewenstein, G., \& Prelec, D. (2012). Measuring the prevalence of questionable research practices with incentives for truth telling. Psychological Science, 23(5), 524-532. https://doi.org/10.1177/0956797611430953

Kahraman, H., \& Kırkıc1, B. (2021). Letter transpositions and morphemic boundaries in the second language processing of derived words: An exploratory study of individual differences. $\quad$ Applied Psycholinguistics, 42(2), 417-446. https://doi.org/10.1017/S0142716420000673

Kathawalla, U.-K., Silverstein, P., \& Syed, M. (2021). Easing into open science: A guide for graduate students and their advisors. Collabra: Psychology, 7(18684). https://doi.org/10.1525/collabra.18684

Kerr, N. L. (1998). HARKing: Hypothesizing after the results are known: Personality and Social Psychology Review. https://doi.org/10.1207/s15327957pspr0203_4

King, G. (2007). An introduction to the dataverse network as an infrastructure for data sharing. Sociological Methods and Research, 36, 173-199.

Klein, R. A., Ratliff, K. A., Vianello, M., Adams, R. B., Bahník, Š., Bernstein, M. J., Bocian, K., Brandt, M. J., Brooks, B., Brumbaugh, C. C., Cemalcilar, Z., Chandler, J., Cheong, W., Davis, W. E., Devos, T., Eisner, M., Frankowska, N., Furrow, D., Galliani, E. M., ... Nosek, B. A. (2014). Investigating variation in replicability: A "Many Labs" Replication Project. Social Psychology, 45(3), 142-152. https://doi.org/10.1027/1864-9335/a000178

Lindsay, D. S., Simons, D. J., \& Lilienfeld, S. O. (2016). Research preregistration 101. APS Observer, 29(10). https://www.psychologicalscience.org/observer/researchpreregistration-101

Marsden, E., Mackey, Alison, \& Plonsky, Luke. (2016). The IRIS Repository: Advancing research practice and methodology. Içinde Advancing Methodology and Practice: The IRIS Repository of Instruments for Research into Second Languages (ss. 1-21). Routledge. https://www.routledge.com/Advancing-Methodology-and-Practice-TheIRIS-Repository-of-Instruments-for/Mackey-Marsden/p/book/9780415833646

Marsden, E., Morgan-Short, K., Thompson, S., \& Abugaber, D. (2018). Replication in second language research: Narrative and systematic reviews and recommendations for the field: Replication in Second Language Research. Language Learning, 68(2), 321391. https://doi.org/10.1111/lang.12286 
Marsden, E., Thompson, S., \& Plonsky, L. (2017). Open science in second language acquisition research: The IRIS repository of research materials and data. SHS Web of Conferences, 38, 00013. https://doi.org/10.1051/shsconf/20173800013

Mertzen, D., Lago, S., \& Vasishth, S. (2020). The benefits of preregistration for hypothesis-driven bilingualism research [Preprint]. PsyArXiv. https://doi.org/10.31234/osf.io/nm3eg

Mertzen, D., Lago, S., \& Vasishth, S. (2021). The benefits of preregistration for hypothesis-driven bilingualism research. Bilingualism: Language and Cognition, 16. https://doi.org/10.1017/S1366728921000031

Miguel, E., Camerer, C., Casey, K., Cohen, J., Esterling, K. M., Gerber, A., Glennerster, R., Green, D. P., Humphreys, M., Imbens, G., Laitin, D., Madon, T., Nelson, L., Nosek, B. A., Petersen, M., Sedlmayr, R., Simmons, J. P., Simonsohn, U., \& Van der Laan, M. (2014). Promoting transparency in social science research. Science, 343(6166), 30-31. https://doi.org/10.1126/science.1245317

Moshontz, H., Binion, G., Walton, H., Brown, B. T., \& Syed, M. (2021). A guide to posting and managing preprints. Advances in Methods and Practices in Psychological Science, 4(2), 25152459211019948. https://doi.org/10.1177/25152459211019948

Mudrak, Ben. (2020). What are preprints, and how do they benefit authors? | AJE. https://www.aje.com/arc/benefits-of-preprints-for-researchers/

Munafò, M., \& Neill, J. (2016). Null is beautiful: On the importance of publishing null results. Journal of Psychopharmacology, 30(7), 585-585. https://doi.org/10.1177/0269881116638813

Nosek, B. A., Ebersole, C. R., DeHaven, A. C., \& Mellor, D. T. (2018). The preregistration revolution. Proceedings of the National Academy of Sciences, 115(11), 2600-2606. https://doi.org/10.1073/pnas.1708274114

Olsson-Collentine, A., van Assen, M. A. L. M., \& Hartgerink, C. H. J. (2019). The prevalence of marginally significant results in psychology over time. Psychological Science, 30(4), 576-586. https://doi.org/10.1177/0956797619830326

Open Science Collaboration. (2015). Estimating the reproducibility of psychological science. Science, $\quad 349(6251), \quad$ aac4716-aac4716. https://doi.org/10.1126/science.aac4716

Roettger, T. B. (2021). Preregistration in experimental linguistics: Applications, challenges, and limitations. Linguistics, $O(0), 000010151520190048$. https://doi.org/10.1515/ling-2019-0048

Roettger, T. B., \& Baer-Henney, D. (2018). Toward a replication culture: Speech production research in the classroom. PsyArXiv. https://doi.org/10.31234/osf.io/q9t7c

Roettger, T., Winter, B., \& Baayen, H. (2019). Emergent data analysis in phonetic sciences: Towards pluralism and reproducibility. Journal of Phonetics, 73, 1-7. https://doi.org/10.1016/j.wocn.2018.12.001

Rosenthal, R. (1979). The file drawer problem and tolerance for null results. Psychological Bulletin, 86(3), 638-641. https://doi.org/10.1037/0033-2909.86.3.638

Schönbrodt, F. (2019). Training students for the Open Science future. Nature Human Behaviour, 3(10), 1031-1031. https://doi.org/10.1038/s41562-019-0726-z

Simmons, J. P., Nelson, L. D., \& Simonsohn, U. (2011). False-positive psychology: Undisclosed flexibility in data collection and analysis allows presenting anything as significant. Psychological Science, 22(11), 1359-1366. https://doi.org/10.1177/0956797611417632 
Simonsohn, U., Nelson, L. D., \& Simmons, J. P. (2013). P-Curve: A key to the file drawer (SSRN Scholarly Paper ID 2256237). Social Science Research Network. https://papers.ssrn.com/abstract=2256237

Spellman, B. A., Gilbert, E. A., \& Corker, K. S. (2018). Open Science. Stevens' Handbook of Experimental Psychology and Cognitive Neuroscience içinde (ss. 1-47). American Cancer Society. https://doi.org/10.1002/9781119170174.epcn519

Szollosi, A., Kellen, D., Navarro, D. J., Shiffrin, R., Rooij, I. van, Zandt, T. V., \& Donkin, C. (2020). Is preregistration worthwhile? Trends in Cognitive Sciences, 24(2), 94-95. https://doi.org/10.1016/j.tics.2019.11.009

The Retraction Watch Leaderboard. (2015, Haziran 16). Retraction watch. https://retractionwatch.com/the-retraction-watch-leaderboard/

United Nations Educational, Scientific and Cultural Organization (UNESCO). (2016). The Future of scientific advice to the United Nations: A summary report to the Secretary-General of the United Nations from the Scientific Advisory Board.

Vasishth, S., Mertzen, D., Jäger, L. A., \& Gelman, A. (2018). The statistical significance filter leads to overoptimistic expectations of replicability. Journal of Memory and Language, 103, 151-175. https://doi.org/10.1016/j.jml.2018.07.004

Vazire, S. (2019). A toast to the error detectors. Nature, 577(7788), 9-9. https://doi.org/10.1038/d41586-019-03909-2

Wicherts, J. M., Bakker, M., \& Molenaar, D. (2011). Willingness to share research data is related to the strength of the evidence and the quality of reporting of statistical Results. PLOS ONE, 6(11), e26828. https://doi.org/10.1371/journal.pone.0026828

Wicherts, J. M., Veldkamp, C. L. S., Augusteijn, H. E. M., Bakker, M., van Aert, R. C. M., \& van Assen, M. A. L. M. (2016). Degrees of freedom in planning, running, analyzing, and reporting psychological studies: A checklist to avoid p-hacking. Frontiers in Psychology, 7. https://doi.org/10.3389/fpsyg.2016.01832 